\title{
Dark Preconditioning, CPPU, and Thidiazuron Promote Shoot Organogenesis on Seedling Node Explants of Common and Faba Beans
}

\author{
Mohamed F. Mohamed ${ }^{1}$, Paul E. Read ${ }^{2}$, and Dermot P. Coyne ${ }^{3}$ \\ Department of Hoticulture, University of Nebraska, Lincoln, NE 68583-0724 \\ Additional index words. benzyladenine, in vitro, Phaseolus vulgaris, plant regeneration, tissue culture, Vicia faba
}

\begin{abstract}
Dry seeds from two lines of common bean (Phaseolus vulgaris L.) and one cultivar of faba bean (Vicia faba L.) were germinated on Murashige and Skoog (MS) medium containing $B_{5}$ vitamins, $30 \mathrm{~g}$ sucrose/liter, and either 2.5, 5.0, or 7.5 $\mu \mathrm{M}$ benzyladenine (BA). Axenic seed cultures were grown at 22 to $24 \mathrm{C}$ in darkness and under continuous light from cool-white fluorescent tubes $\left(40 \mu \mathrm{mol} \cdot \mathrm{m}^{-2} \cdot \mathrm{s}^{-1}\right)$. Explant tissues were prepared from cotyledonary nodes $(\mathrm{CN})$ and primary nodes $(\mathrm{PN})$ of 14-day-old seedlings. Explants were cultured on corresponding seedling growth medium and maintained under continuous cool-white light $\left(40 \mu \mathrm{mol} \cdot \mathrm{m}^{-2} \cdot \mathrm{s}^{-1}\right)$. The percentages of $\mathrm{CN}$ and PN (in one line of common bean) explants that regenerated shoots and the number of shoots per explant (in all germplasm) were highest when nodal tissues were prepared from seedlings germinated in darkness. These responses were optimal on medium containing $5 \mu \mathrm{M}$ BA during seedling growth and subsequent culture of explants. The number of shoots per explant was two to five times higher on explants cultured on medium with 0.25 to $1.0 \mu$ m forchlorfenuron (CPPU) or thidiazuron (TDZ) than on medium with $5 \mu \mathrm{M} \mathrm{BA}$. Higher ( 2.5 and $5 \mu \mathrm{M})$ CPPU and TDZ concentrations inhibited shoot elongation and stimulated callus production. Histological analyses indicated that adventitious meristems formed 6 to 8 days after explant culture. Progenies from regenerated plants appeared similar to plants raised from the original seed stocks. Chemical names used: $N$ - (phenylmethyl) -1 $\mathrm{H}$ - purin-6-amine (benzyladenine, BA); $N$ - (2-chloro-4-pyridyl)$N^{\prime}$ - phenylurea (forchlorfenuron, CPPU); $N$ - phenyl - $N^{\prime}$-1,2,3-thiadiazol-5-ylurea (thidiazuron, TDZ).
\end{abstract}

Tissue culture of grain legumes using cotyledonary node explants from in vitro-grown seedlings has been documented for organogenic competence (Jackson and Hobbs, 1990; McClean and Grafton, 19889; Wright et al., 1986). BA supplements (5 to $10 \mu \mathrm{M})$ in the medium during germination and subsequent explant culture were one of the most critical factors for organogenic differentiation and shoot multiplication in this regeneration system. $N$ - (2-furanylmethyl)-1 $H$ - purin-6-amine (kinetin) was ineffective (McClean and Grafton, 1989) for inducing multiple-shoot organogenesis in common bean or in pea (Pisum sativum L.) (Jackson and Hobbs, 1990), and neither (E)-2-methyl4-(1H-purin-6-ylamino)-2-buten-1-ol (zeatin) nor $N$ - (3-methyl2-butenyl)-1 $H$ - purin-6-amine (2iP) could be substituted for BA in soybean [Glycine $\max (\mathrm{L}$.) Merr.] shoot regeneration studies (Wright et al., 1986).

Recently, some cytokinin-like compounds of nonpurine structure have been used in tissue-culture research. These compounds, which include forchlorfenuron (CPPU) and thidiazuron (TDZ), have exhibited stronger cytokinin-like effects than conventional cytokinins on a wide range of species [Ohyama and Oka (1982) in mulberry (Morus alba L.); Nieuwkerk et al. (1986) in apple (Malus domestica Borkh.); Fellman et al. (1987) in azaleas (Rhododendron spp.); Mohamed-Yasseen and Splittstoesser (1990) in soybean]. In addition, dark-incubation of em-

\footnotetext{
Received for publication 25 Nov. 1991. Accepted for publication 18 Feb. 1992. Published as paper no. 9769, Journal Series, Nebraska Agricultural Research Division. Research was conducted under Title XII Bean/Cowpea CRSP Project, Univ. of Nebraska, Univ. of Puerto Rico, and Dominican Republic under AID contract no. DNA-1310-G-SS-6008-00 and also under Project no. 20-036. The senior author thanks Ellen Paparozzi for her review of this manuscript and Liz Conley for her technical assistance in the histological analyses. The cost of publishing this paper was defrayed in part by the payment of page charges. Under postal regulations, this paper therefore must be hereby marked advertisement solely to indicate this fact.

${ }^{1}$ Visiting Scientist from Dept. of Horticulture, University of Assiut, Assiut, Egypt.

${ }^{2}$ Professor and Head.

${ }^{3}$ George Holmes Regents Professor.
}

bryonic axes from common and tepary beans (P. acutifolius A. Gray) on medium containing BA was found to stimulate shoot bud initiation on explants when transferred under the light (Mohamed et al., 1992).

To our knowledge, there is no report on the effect of darkness during seedling growth before nodal explant excision or on the use of CPPU or TDZ to induce shoot bud organogenesis in common bean or faba bean. The purpose of this study, therefore, was to investigate the effects of these factors on adventitious shoot bud organogenesis.

\section{Materials and Methods}

\section{General methods}

Plant material. Two common bean lines, Xan-159 and Pinto 'Agate', and one cultivar of faba bean, 'Coprosi', were used. Xan-159 (origin, CIAT, Cali, Colombia) was selected because its shoot regeneration competence is higher than for many other common bean lines (Mohamed et al., 1992). Pinto 'Agate' (origin, Rogers/UK, Idaho) is grown commercially in the United States. 'Coprosi' (source, Univ. Assiut, Egypt) is the most popular faba bean cultivar for green consumption in Egypt. Seeds of common and faba beans were increased, then sized for uniformity for use in tissue-culture experiments during 1990 and 1991.

Seed germination, explant preparation and culture conditions. Axenic seed cultures of common and faba beans were established by surface-disinfesting dry seeds in $70 \%$ ethanol for 2 min followed by $15 \mathrm{~min}$ in $0.5 \%$ sodium hypochlorite $(10 \%$ Clorox plus two drops Tween-20 per liter). Unwrinkled seeds were rinsed three times with sterile deionized water and germinated on MS medium (Murashige and Skoog, 1962) with B vitamins (Gamborg et al., 1968), $30 \mathrm{~g}$ sucrose/liter and $6 \mathrm{~g}$ agar/liter (Difco Labs, Detroit). Seed germination medium was

$\overline{\text { Abbreviations: }} \mathrm{CN}$, cotyledonary nodes; $\mathrm{PN}$, primary nodes. 
supplemented with either BA, CPPU, or TDZ and adjusted with $\mathrm{HCl}$ or $\mathrm{NaOH}$ to $\mathrm{pH} 5.7$ before being autoclave $\left(1.4 \mathrm{~kg} \cdot \mathrm{cm}^{-2}\right.$ at $121 \mathrm{C}$ for $20 \mathrm{~min}$ ). Seeds of common bean lines were cultured in $25 \times 150-\mathrm{mm}$ pyrex tubes that contained $15 \mathrm{ml}$ medium. Faba bean seeds, being large, were planted in $45 \times 100-\mathrm{mm}$ baby food jars with $20 \mathrm{ml}$ medium. Axenic seed cultures were kept for 14 days in darkness or under continuous light (40 $\mu \mathrm{mol} \cdot \mathrm{m}^{-2} \cdot \mathrm{s}^{-1}$, from cool-white fluorescent tubes (unless otherwise stated).

Cotyledonary node $(\mathrm{CN})$ explants of common and faba beans consisted of $5 \mathrm{~mm}$ of hypocotyl and epicotyl tissues with 2 to $3 \mathrm{~mm}$ of the attached cotyledons. Primary node (PN) explants of common bean included 1 to $2 \mathrm{~mm}$ of the leaf petiole attached to the stem node. Before explant culture, all visible axillary shoots were removed. $\mathrm{CN}$ and $\mathrm{PN}$ nodes were then gently scraped at the axillary regions to disrupt any preexisting meristems and to stimulate adventitious meristem organogenesis (McClean and Grafton, 1989). The prepared nodal tissues were placed basipetally on fresh medium corresponding to seedling growth medium and maintained at 22 to $24 \mathrm{C}$ under continuous cool-white light $\left(40 \mu \mathrm{mol} \cdot \mathrm{m}^{-2} \cdot \mathrm{s}^{-1}\right)$.

\section{Specific experiments}

Effects of dark preconditioning and BA concentrations (Expt. 1). Seeds from each line of common and faba beans were germinated in a separate experiment conducted as a split plot with four replicates. The whole-plot treatments were dark vs. continuous light and the split-plot treatments were 2.5, 5, and 7.5 $\mu$ M BA (McClean and Grafton, 1989). Each treatment was applied to 16 seeds per replicate (one seed per tube or jar), and explants were prepared from eight seedlings selected at random from each replicate and split-plot treatment. Thus, experiments for the explant cultures were in the same replicates as the germination experiments. $\mathrm{CN}$ and $\mathrm{PN}$ explants from common bean were cultured in separate experiments.

The percentage of $\mathrm{CN}$ and $\mathrm{PN}$ explants that regenerated adventitious shoot buds was recorded 3 weeks after culture initiation. Regenerative explants were then split longitudinally into two halves to encourage shoot elongation and subculture to fresh medium of the same composition. Elongated shoots $(0.5$ to $1 \mathrm{~cm}$ ) were harvested regularly to allow the development of other shoot buds. Proliferative explants were subculture to fresh medium every 3 weeks. The number of excisable shoots $(0.5$ to $1 \mathrm{~cm}$ ) per explant per harvest was summed over 2 to 3 months. Based on the results obtained from these experiments, $5 \mu \mathrm{M}$ was selected as the standard BA level for subsequent comparisons with various concentrations of CPPU and TDZ in the seed germination and explant culture media.

Effects of CPPU and TDZ (Expt. II). All seed cultures for Expt. II were kept in darkness because of enhancement effects of dark-incubation on shoot regeneration from nodal explants (Expt. I). The medium for seed germination contained CPPU or TDZ at 2.5 or $5.0 \mu \mathrm{M}$. BA at $5.0 \mu \mathrm{M}$ was the control treatment. Due to abnormal shoot regeneration on medium containing 2.5 or $5 \mu \mathrm{M} \mathrm{CPPU}$ or TDZ, additional experiments were conducted with $0.25,0.5,0.75$, and $1 \mu \mathrm{M}$ CPPU and TDZ.

Separate experiments for seed germination were conducted for each line from common and faba beans. All experiments were conducted as a randomized complete-block design with four replications. Each replicate consisted of the different CPPU and TDZ concentrations, and a control (BA at $5 \mu \mathrm{M})$. Each treatment was applied to 16 seeds per replicate. $\mathrm{CN}$ and $\mathrm{PN}$ explants were prepared from eight randomly selected seedlings within each replicate from each treatment. Each type of explant (CN and PN) was cultured in separate experiments. The percentage of $\mathrm{CN}$ and $\mathrm{PN}$ explants regenerating adventitious shoots and number of shoots per explant were recorded as in Expt. I.

Axillary shoots $(0.5$ to $1 \mathrm{~cm})$ removed during preparation of the nodal explants in these later experiments were saved and transferred to half-strength MS with $\mathrm{B}_{5}$ vitamins, $20 \mathrm{~g}$ sucrose/ liter, and $7 \mathrm{~g}$ agar/liter but without plant growth regulators. The same medium was used to induce roots on common bean shoots that regenerated from $\mathrm{CN}$ and $\mathrm{PN}$ explants or proliferated from axillary shoot cultures. This medium, but with $2 \mathrm{~g}$ charcoal/liter or 1 to $2 \mu \mathrm{M} \alpha$ - naphthaleneacetic acid (NAA), was used to induce roots on faba bean shoots. In vitro plantlets from common and faba beans were acclimatized under a mist chamber in plastic pots containing 0.4 liter of 1 sphagnum peat : 1 vermiculite (v/v) mixture. These plantlets were transferred to clay pots (1.8 liters) containing 2 soil : 2 sand : 2 sphagnum peat : 1 vermiculite (by volume) potting medium and grown to maturity at 25 to $27 \mathrm{C}$ in the greenhouse.

Greenhouse study. Plants regenerated from shoot organogenesis in Expt. II were observed during their growth, along with those plants propagated from preexisting axillary shoots. Progenies from these in vitro-derived plants were then compared with plants raised from original seed stocks. The experiments for the evaluation of the different progenies were conducted as randomized complete blocks for each line of common and faba beans, separately. Forty-eight plants were grown from each progeny line (16 plants per each of three replicates), and data for plant height, flowering and maturity times, flower and seed color, and seed size were recorded.

Histological study. Samples were collected from CN and PN explants at 2-day intervals from the time of culture initiation and up to 12 days. Explants were fixed in FAA: 100\% ethanol/ glacial acetic acid $/ 40 \%$ formalin $(10: 1: 2+7$ parts of water, by volume), dehydrated in an ethanol/Hemo-De series, infiltrated, and embedded in paraplast. Microtome longitudinal sections were cut at $15 \mu \mathrm{m}$, mounted on glass slides, dewaxed in Hemo-De, and dehydrated in a descending ethanol series. Sections were stained with safranin- 0 for $2 \mathrm{~h}$ followed by $5 \mathrm{sec}$ in fast green.

\section{Results and Discussion}

Effects of dark preconditioning and BA concentrations (Expt. 1). Axenic seed cultures of common and faba beans germinated on BA media under cool-white light developed into compact dark-green seedlings with thick nodes after 14 days. Multiple shoot bud initials ( 1 to $2 \mathrm{~mm}$ ) were induced at the cotyledonary node region of most seedlings. Primary roots were short and thick, and secondary root growth was inhibited. Soybean seedlings responded similarly (Cheng et al., 1980; Mohamed-Yasseen and Splittstoesser, 1990; Wright et al., 1986). These effects are due to cytokinins reducing apical dominance and inhibiting root development (Seidlova and Krekule, 1977; Stenlid, 1982). Seedlings grown in darkness had clearly distinguishable nodes and long axillary shoots that were easily removed. Multipleaxillary shoots ( 5 to $10 \mathrm{~mm}$ ) were induced on both sides of the cotyledonary node region in all seedlings under this treatment.

There was no significant interaction between the explant source from the different preconditioning treatments and BA level in the culture medium. The percentage of explants regenerating adventitious shoots and the number of shoots per explant were higher when $\mathrm{CN}$ explants were prepared from seedlings grown in darkness than from those in continuous light for both common 
and faba beans (Table 1). Cultures from PN explants of common bean gave similar results, except for the percentage of explants regenerating shoots in Pinto 'Agate'. Dark incubation suppressed shoot development from embryonic explants cultured on BA-containing medium while it was stimulating the development of callus tissues and initial shoot organogenesis from that callus [Barwale et al. (1986) in soybean] or large meristematic regions and direct shoot bud organogenesis [Mohamed et al. (1992) in common bean and tepary bean]. Preincubation of leaf explants in darkness was essential to initiate shoot organogenesis in three Cucumis spp. (Punja et al., 1990) and also in Pyrus communis L. (Leblay et al., 1991). The length of dark pretreatment differed among these plant species, and it was terminated when the explant had formed sufficient callus or start organ differentiation. Prolonged incubation in darkness induced adverse effects that suppressed regeneration (Punja et al., 1990). Light was required for growth and development of the differentiated organs in all cases, indicating that dark-stimulative effects on regeneration maybe related to induction of competence in callus or primary explant tissues.

The BA concentration in the seedling growth medium and explant culture medium for common bean did not affect the percentage of $\mathrm{CN}$ and $\mathrm{PN}$ explants that regenerated adventitious shoots. However, the number of shoots per explant changed quadratically such that $5 \mu \mathrm{M}$ BA was optimal. The percentage of faba bean $\mathrm{CN}$ explants that regenerated adventitious shoots was a linear response, with equal regeneration at 5 and $7.5 \mu \mathrm{M}$ BA. The number of shoots per explant of faba bean gave quadratic response with the optimal point at $5 \mu \mathrm{M} \mathrm{BA}$. These results are similar to those of McClean and Grafton (1989) for shoot organogensis on common bean $\mathrm{CN}$ explants. However, Franklin et al. (1991) obtained adventitious shoots on BA medium only when explants consisted of axillary buds with cotyledons attached. These differences are attributed to intraspecific genotypic variation, indicating that the regeneration protocols may be genotype-dependent. Our data further suggest that explants from-the first primary node could be employed and that dark incubation during seedling pretreatment before explant excision is beneficial.

Effects of CPPU and TDZ (Expt. II). Nodal cultures of common bean prepared from seedlings grown on 2.5 or $5 \mu \mathrm{M} \mathrm{CPPU}$

Table 1. Effect of light vs. darkness during seedling preconditioning and of BA concentration (micromoles) on the percentage of common bean, Xan-159 (CBX) and Pinto 'Agate' (CBP), and faba bean 'Coprosi' (FBC) $\mathrm{CN}$ and $\mathrm{PN}$ explants that regenerated adventitious shoots after 3 weeks and the number of shoots $(0.5$ to $1.0 \mathrm{~cm})$ per explant after 2 to 3 months.

\begin{tabular}{|c|c|c|c|c|c|c|c|c|c|c|}
\hline \multirow{3}{*}{$\begin{array}{l}\text { Preconditioning } \\
\text { treatments }^{z}\end{array}$} & \multicolumn{5}{|c|}{$\begin{array}{l}\text { Nodal explants develop- } \\
\text { ing new shoots }(\%)\end{array}$} & \multicolumn{5}{|c|}{ Shoots/explant (no.) } \\
\hline & \multicolumn{2}{|c|}{$\mathrm{CBX}$} & \multicolumn{2}{|c|}{ CBP } & \multirow{2}{*}{$\frac{\mathrm{FBC}}{\mathrm{CN}}$} & \multicolumn{2}{|c|}{ CBX } & \multicolumn{2}{|c|}{ CBP } & \multirow{2}{*}{$\frac{\mathrm{FBC}}{\mathrm{CN}}$} \\
\hline & $\mathrm{CN}$ & PN & $\mathrm{CN}$ & PN & & $\mathrm{CN}$ & PN & $\mathrm{CN}$ & PN & \\
\hline Light & 66 & 31 & 50 & 16 & 31 & 3.3 & 0.7 & 1.8 & 0.3 & 1.4 \\
\hline Darkness & 87 & 54 & 77 & 21 & 58 & 5.0 & 1.4 & 3.2 & 1.0 & 2.9 \\
\hline $\begin{array}{l}\operatorname{LSD}_{0.05} \\
\operatorname{BA}(\mu M)\end{array}$ & 13 & 18 & 16 & NS & 12 & 0.9 & 0.5 & 0.8 & 0.4 & 0.6 \\
\hline 2.5 & 71 & 43 & 62 & 16 & 28 & 2.1 & 0.5 & 2.0 & 0.4 & 1.1 \\
\hline 5.0 & 84 & 50 & 68 & 34 & 53 & 6.3 & 1.4 & 3.1 & 1.0 & 2.7 \\
\hline 7.5 & 75 & 34 & 59 & 31 & 53 & 4.0 & 1.0 & 2.5 & 0.6 & 2.6 \\
\hline Contrast ${ }^{y}$ & NS & NS & NS & NS & $\mathrm{L}$ & $\mathrm{Q}$ & Q & $\mathrm{Q}$ & $\mathrm{Q}$ & $\mathbf{Q}$ \\
\hline
\end{tabular}

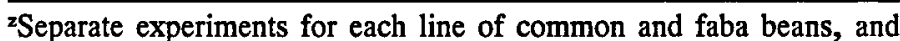
explant type.

$\mathrm{y} L=$ linear, $\mathrm{Q}=$ quadratic, $\mathrm{NS}=$ not significant. or TDZ regenerated shoot buds in the form of rosettes, but no excisable shoots developed. The formation of these shoot buds was associated with callus on the basal cut surface of the explant. Callus induction was most pronounced on medium containing $5 \mu \mathrm{M}$ CPPU or TDZ. Callus on TDZ medium was nodular and greenish-yellow, whereas CPPU induced compact and brownish-yellow callus. Similar effects were observed in faba bean, but the callus was less pronounced and had a compact texture and was brownish-black. Soybean shoots appeared stunted, with abnormal leaves (Mante et al., 1989), when regenerated from cotyledon explants incubated on medium containing 5 to $7.5 \mu \mathrm{M}$ TDZ. Using lower concentrations $(0.25$ to $1.0 \mu \mathrm{M})$ of CPPU or TDZ in seed germination and $\mathrm{CN}$ culture media for common bean resulted in normal shoot bud initiation (Fig. 1A) and development (Fig. 1B) without associated callus. These concentrations of CPPU and TDZ were also suitable for normal shoot regeneration from common bean $\mathrm{PN}$ and faba bean $\mathrm{CN}$.

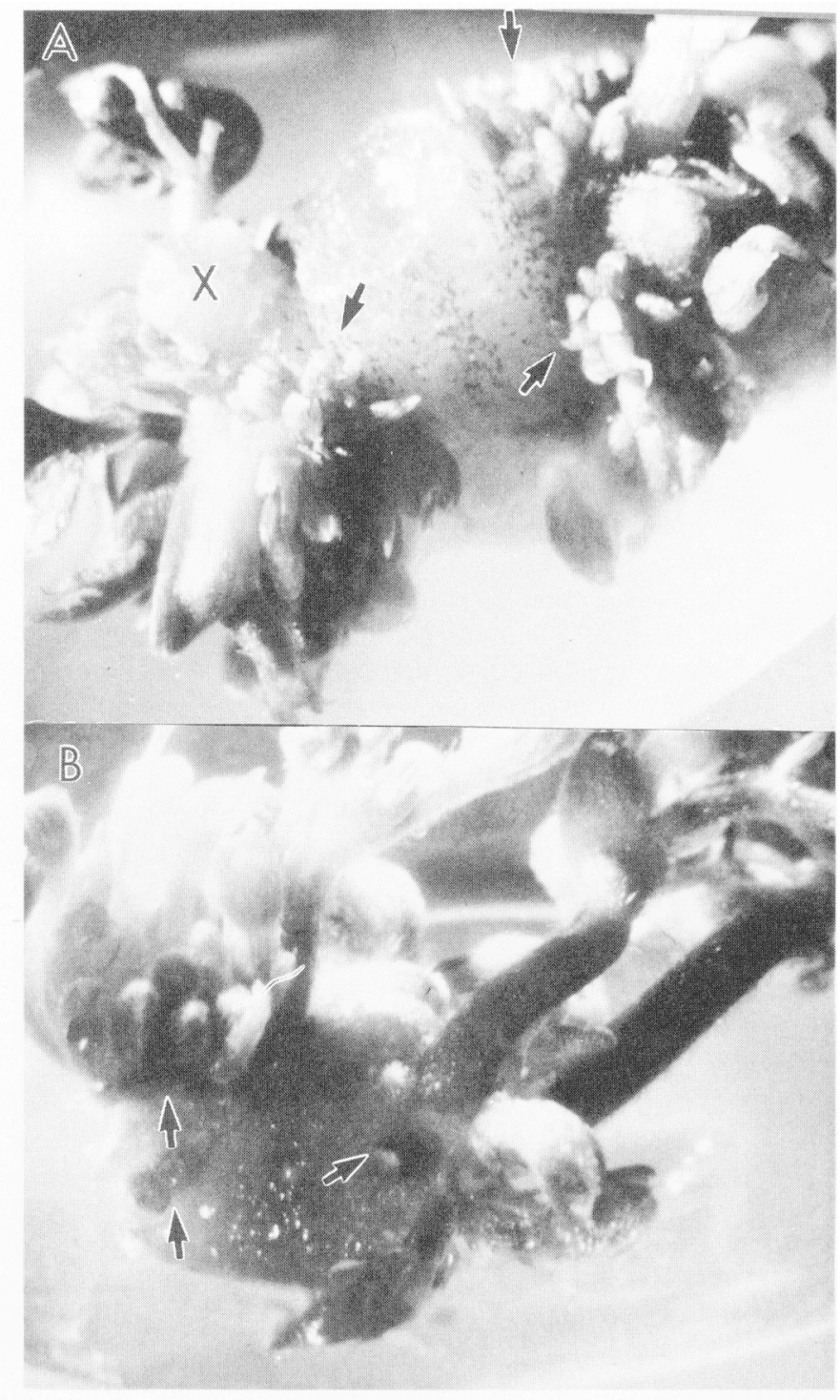

Fig. 1. (A) Common bean $\mathrm{CN}$ explants incubated for 3 weeks on medium containing 0.25 to $1.0 \mu \mathrm{M}$ TDZ or CPPU showing normal shoot buds (arrows) initiated around the removed axillary shoots (X). (B) Shoot elongation on a split $\mathrm{CN}$ explant of common bean incubated for 6 weeks on medium containing $0.25 \mu \mathrm{M}$ CPPU or TDZ. Note the shoot-bud initials developing on the explant (arrows). 
Adventitious meristems were observed 6 to 8 days after culture of common bean CN (Fig. 2) and PN, and faba bean CN. Different concentrations of CPPU or TDZ did not affect the percentage of common bean $\mathrm{CN}$ and $\mathrm{PN}$ explants that regenerated shoots (Table 2). However, the number of shoots per explant decreased linearly, except for Pinto 'Agate' PN explants, with increasing levels of CPPU or TDZ. Although more shoots were present at $0.5 \mu \mathrm{M}$ CPPU, no significant quadratic response was detected. Therefore, the best response for shoot regeneration occurred at the lowest CPPU concentration $(0.25 \mu \mathrm{M})$. The most shoots per explant among common bean lines were observed at $0.25 \mu \mathrm{M}$ TDZ. Higher CPPU and TDZ concentrations increase both the percentage of faba bean explants regenerating adventitious shoots and the number of shoots per explant. The func-

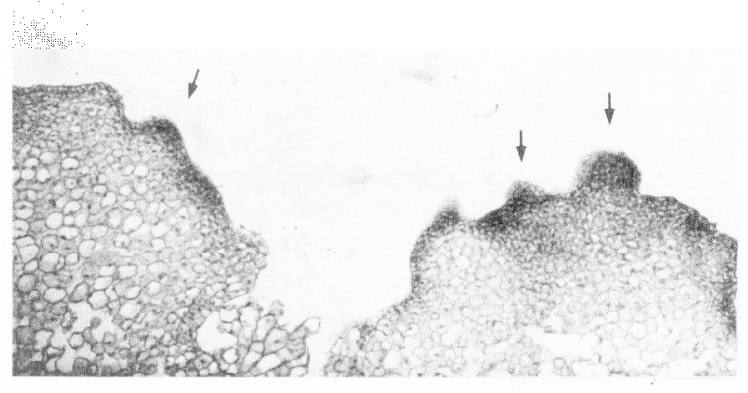

Fig. 2. Longitudinal thin section through a $\mathrm{CN}$ explant from common bean 6 to 8 days after culture on medium containing 0.25 to $1 \mu \mathrm{M}$ CPPU or TDZ. Note the initiation of several adventitious meristems and buds (arrows).

Table 2. The percentages of common bean, Xan-159 (CBX) and Pinto 'Agate' (CBP), and faba bean 'Coprosi' (FBC) $\mathrm{CN}$ and PN regenerating adventitious shoots after 3 weeks, and the number of shoots ( 0.5 to $1.0 \mathrm{~cm}$ ) per explant after 2 to 3 months on medium containing $5 \mu \mathrm{M}$ BA or different concentrations (micromoles) of forchlorfenuron (CPPU) or thidiazuron (TDZ).

\begin{tabular}{|c|c|c|c|c|c|c|c|c|}
\hline \multirow[b]{3}{*}{ Treatment ${ }^{z}$} & \multicolumn{3}{|c|}{$\begin{array}{c}\text { Nodal explants } \\
\text { developing new shoots } \\
(\%)\end{array}$} & \multicolumn{5}{|c|}{ Shoots/explant (no.) } \\
\hline & $\mathrm{CBX}$ & \multirow{2}{*}{ CBP } & \multirow{2}{*}{$\frac{\mathrm{FBC}}{\mathrm{N}} \frac{\mathrm{CN}}{\mathrm{CN}}$} & \multicolumn{2}{|c|}{$\mathrm{CBX}$} & \multicolumn{2}{|c|}{ CBP } & \multirow{2}{*}{$-\frac{\mathrm{FBC}}{\mathrm{CN}}$} \\
\hline & $\overline{\mathrm{CN}} \mathrm{PN}$ & & & $\mathrm{CN}$ & PN & $\mathrm{CN}$ & PN & \\
\hline Control (5 $\mu \mathrm{M} \mathrm{BA})$ & 9353 & 8428 & 43 & 7.1 & 1.3 & 4.3 & 0.5 & 2.5 \\
\hline $\mathrm{CPPU}(\mu \mathrm{\mu N}$ & & & & & & & & \\
\hline $\begin{array}{l}0.25 \\
0.50\end{array}$ & $\begin{array}{l}10065 \\
10075\end{array}$ & $\begin{array}{l}10059 \\
10059\end{array}$ & $\begin{array}{l}02 \\
75\end{array}$ & $\begin{array}{l}15.8 \\
16.7\end{array}$ & $\begin{array}{l}2.3 \\
4.3\end{array}$ & 8.5 & 2.2 & 3.8 \\
\hline 0.75 & 10062 & 10056 & 78 & 12.7 & 2.0 & 6.5 & 1.5 & 4.7 \\
\hline 1.00 & 10059 & 10050 & 93 & 11.5 & 2.0 & 5.6 & 1.2 & 6.2 \\
\hline $\begin{array}{l}\text { Contrast } \\
\mathrm{TDZ}(\mu \mathrm{M})\end{array}$ & NS NS & NS NS & $\mathrm{L}$ & $\mathrm{L}$ & $\mathrm{L}$ & L & NS & $\mathrm{L}$ \\
\hline 0.25 & 10075 & 10050 & 56 & 16.0 & 4.8 & 9.5 & 2.5 & 2.3 \\
\hline 0.5 & 10065 & 10056 & 68 & 11.8 & 2.3 & 7.0 & 1.8 & 4.7 \\
\hline 0.75 & 10062 & 10053 & 71 & 10.7 & 2.3 & 5.8 & 1.5 & 5.0 \\
\hline 1.00 & 10056 & 10046 & 93 & 8.5 & 1.8 & 4.5 & 1.5 & 6.5 \\
\hline Contrast & NS NS & NS NS & $\mathrm{L}$ & $\mathrm{L}$ & $\mathrm{L}$ & $\mathrm{L}$ & NS & $\mathrm{L}$ \\
\hline Significan & & & & & & & & \\
\hline Control vs. others & ${ }^{* *}$ NS & *** $*$ & ** & ** & ** & ** & ** & ** \\
\hline TDZ vs. CPPU & NS NS & NS NS & NS & NS & NS & NS & NS & NS \\
\hline
\end{tabular}

${ }^{\mathrm{z}}$ Separate experiments for each line of common and faba beans, and explant type.

${ }^{\mathrm{NS}, *, * * *}$ Nonsignificant and significant at $P<0.05$ or 0.01 , respectively. $\mathrm{L}=$ Linear response. tions were linear, and the best responses occurred at $1 \mu \mathrm{M} \mathrm{CPPU}$ or TDZ.

The overall concentration effects of TDZ vs. CPPU were not significant for both common ( $\mathrm{CN}$ and $\mathrm{PN}$ explants) and faba (CN explants) beans, indicating similar effectiveness of these two cytokinin-like substances to stimulate shoot bud induction at relatively low concentrations. In addition, the number of shoots per explant was two to five times higher when $\mathrm{CN}$ and $\mathrm{PN}$ explants were incubated on medium containing 0.25 to $1 \mu \mathrm{M}$ CPPU or TDZ compared with the optimum BA concentration.

However, the multiple-axillary shoots that were removed from seedlings grown on CPPU and TDZ media proliferated 5.3 and 4.6 shoot branches, respectively, on medium without plant regulators. These values were higher $(P<0.05)$ than those $(3.1$ shoot branches) from axillary shoots of seedlings grown on BA medium $(5 \mu \mathrm{M})$. Mohamed-Yasseen and Splittstoesser (1990) reported similar effects on medium containing $0.14 \mu \mathrm{M}$ TDZ and $5 \mu \mathrm{M}$ BA on shoot induction from soybean $\mathrm{CN}$ explants. Both CPPU and TDZ have been shown to be effective cytokininlike compounds at lower concentrations when compared with the conventional cytokinins (Fellman et al., 1987; Nieuwkerk et al., 1986; Ohyama and Oka, 1982; Preece et al., 1991).

Shoot production was continuous from nodal explants during the two subcultures following the culture initiation. Every 10 days, new shoots were harvested and transferred to rooting medium. Roots were induced after 7 to 10 days on half-strength medium without plant growth regulators for all common bean shoots. Faba bean shoots formed roots only on medium containing $2 \mathrm{~g}$ charcoal/liter or 1 to $2 \mu \mathrm{M} \mathrm{NAA}$ (Fig. 3).

Greenhouse study. Plants regenerated via shoot organogenesis and axillary shoot proliferation grew normally in the greenhouse and produced viable seeds. McClean and Grafton (1989) reported variability for plant height, maturity, and seed coat color in common bean plants regenerated via direct shoot organogenesis from $\mathrm{CN}$ explants. On the contrary, all plants regenerated from common bean via direct shoot organogenesis (Franklin et al., 1991) from seedling explants (cotyledon attached with 2 to $3 \mathrm{~mm}$ of the embryonic axis) or from common and tepary beans from embryonic axis explants (Mohamed et al., 1992) were normal for height, flowering, and pod set. Variability was not detected in soybean using this organogenic regeneration system (Wright et al., 1986). Flower and seed color

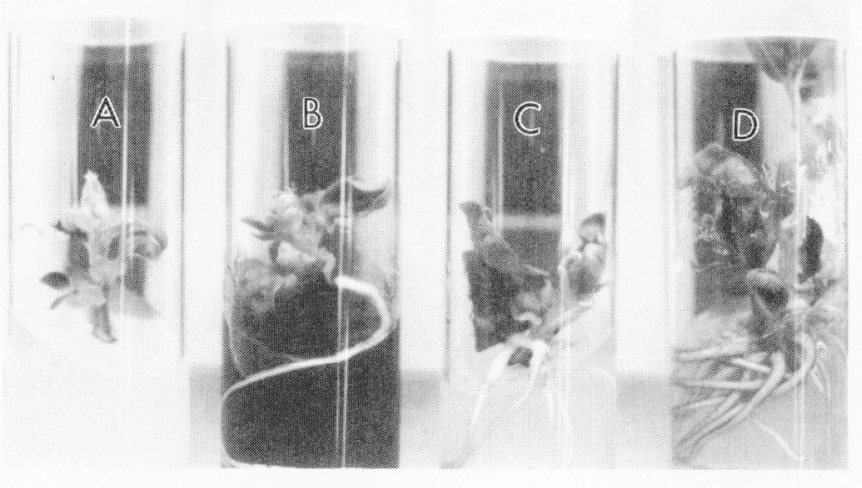

Fig. 3. The effect of four media on root induction in faba bean shoots transferred to (A) medium without plant growth regulators, (B) medium containing $2 \mathrm{~g}$ activated charcoal/liter, or transferred to medium containing $1 \mu \mathrm{M}(\mathbf{C})$ or $2 \mu \mathrm{M}$ (D) NAA. 
for progenies of plants regenerated via organogensis from common and faba beans were the same as those plants produced from axillary shoot micropropagation and plants raised from the original seed stocks. Quantitative traits such as plant height, flowering and maturity times, and seed size were similar.

The system we described for shoot organogenesis and plant regeneration from seedling nodes maybe beneficial for genetic transformation studies. Regeneration of many shoots via new meristem organogensis from nodal tissues of 14-day-old seedlings grown in darkness and the use of medium containing TDZ or CPPU may provide an opportunity for more individual cells to undergo transformation, thus potentially increasing the number of individual transformants produced per explant.

\section{Literature Cited}

Barwale, U.B., H.R. Kerns, and J.M. Widholm. 1986. Plant regeneration from callus cultures of several soybean genotypes via embryogenesis and organogensis. Planta 167:473-481.

Cheng, T.Y., H. Saka, and T.H. Voqui-Dinh. 1980. Plant regeneration from soybean cotyledonary node segments in culture. Plant Sci. Lett. 19:91-99.

Fellman, C.D., P.E. Read, and M.A. Hosier. 1987. Effects of thidiazuron and CPPU on meristem formation and shoot proliferation. HortScience 22:1197-1200.

Franklin, C.I., T.N. Trieu, R.A. Gonzales, and R.A. Dixon. 1991. Plant regeneration from seedling explants of green bean (Phaseolus vulgaris L.) via organogenesis. Plant Cell Tissue Organ Cult. 24:199 206.

Gamborg, O.L., R.A. Miller, and K. Ojima. 1968. Nutrient requirements of suspension cultures of soybean root cells. Expt. Cell Res. 50:151-158.

Jackson, J.A. and S.L. Hobbs. 1990. Rapid multiple shoot production from cotyledonary node explants of pea (Pisum sativum L.). In Vitro Cellular Dev. Biol. 26:835-838.

Leblay, C., E. Chevreau, and L.M. Raboin. 1991. Adventitious shoot regeneration from in vitro leaves of several pear cultivars (Pyrus communis L.). Plant Cell Tissue Organ Cult. 25:99-106.

Mante, S., R. Scorza, and J. Cordts. 1989. A simple, rapid protocol for adventitious shoot development from mature cotyledons of Glycine max CV. Bragg. In Vitro Cellular Dev. Biol. 25:385-388.

McClean, P. and K.F. Grafton. 1989. Regeneration of dry bean (Phaseolus vulgaris L.) via organogenesis. Plant Sci. 60:117-122.

Mohamed, M.F., P.E. Read, and D.P. Coyne. 1992. Plant regeneration from in vitro culture of embryonic axis explants in common and tepary beans. J. Amer. Soc. Hort. Sci. 117:332-336.

Mohamed-Yasseen, Y. and W.E. Splittstoesser. 1990. Regeneration of soybean [Glycine $\max ($ L.) Merr.] from the seedling apex, stem node, cotyledonary node and cotyledons. Plant Growth Regulat. Soc. Amer. Quart. 18:203-210.

Murashige, T. and F. Skoog. 1962. A revised medium for rapid growth and bioassays with tobacco tissue cultures. Physiol. Plant. 15:473497.

Nieuwkerk, J.P., R.H. Zimmerman, and I. Fordham. 1986. Thidiazuron stimulation of apple shoot proliferation in vitro. HortScience 21:516-518.

Ohyama, K. and S. Oka. 1982. Multiple shoot formation from mulberry (Morus alba L.) hypocotyls by N-(2-chloro-4-pyridyl)-N'phenylurea. Proc. 5th Intl. Congr. Plant Tissue Cell Cult. p. 149150.

Preece, J.E., C.A. Huetteman, W.C. Ashby, and P.L. Roth. 1991. Micro- and cutting propagation of silver maple I. Results with adult and juvenile propagules. J. Amer. Soc. Hort. Sci. 116:142-148.

Punja, Z.K., N. Abbas, G.G. Sarmento, and F.A. Tang. 1990. Regeneration of Cucumis sativus var. sativus and Cucumis sativus var. hardwickii, Cucumis melo and Cucumis metuliferus from explants through somatic embryogenesis and organogenesis: Influence of explant source, growth regulator regime and genotype. Plant Cell Tissue Organ Cult. 21:93-102.

Seidlova, F. and J. Krekule. 1977. Effects of kinetic on growth of apical meristem and floral differentiation in Chenopodium rubrum L. Ann. Bot. 41:755-763.

Stenlid, G. 1982. Cytokinins as inhibitors of root growth. Physiol. Plant 55:500-506.

Wright, M.S., M.G. Carnes, M.A. Hinchee, G.C. Davis, S.M. Koehler, M.H. Williams, S.M. Colburn, and P.E. Pierson. 1986. Plant regeneration from tissue cultures of soybean by organogenesis, $\mathrm{p}$. 111-119 In: I.K. Vasil (ed.). Cell culture and somatic cell genetics of plants, vol. 3, Academic, New York. 